\title{
Solar energy available and energy generated in photovoltaic systems in different inclinations and orientations of roofs of buildings
}

\author{
Energia solar disponível e energia geradla em sistemas fotovoltaicos em diferentes inclinações e \\ orientações de telhados de edificações \\ Energía solar disponible y energía generada en sistemas fotovoltaicos en diferentes inclinaciones y \\ orientaciones de tejados de edificios
}

\begin{abstract}
This work aimed to determine the solar energy available in different inclinations and orientations of roofs of buildings in the four seasons, using data of Global Solar Irradiation in the horizontal plane, temperatures, and wind speed. The inclined hourly solar irradiation and the energy generated by photovoltaic systems of different capacities installed in Cascavel-PR were simulated, with different orientations and inclinations and types of roofs (ceramic, fiber cement and metal). SWERA (Solar and Wind Energy Resource Assessment) daily global solar irradiation and wind velocity data were used to simulate daily inclined global solar irradiation in PVSyst software. Thus, also with the help of the software, the energy generated by photovoltaic systems of different capacities installed in Cascavel - PR, with different orientations and inclinations of roofs was determined. Consequently, the levels of losses in different seasons of the year were calculated and an analysis of the economic viability of the undertakings was made. Thus, the losses, profits and income of the systems were compared. Solar panels installed in northern oriented ceramic roofs provide better energy production performance throughout the year compared to metallic roofs and fibrocement. However, for the other orientations (South, East and West), the losses for ceramic roofs were twice as high as the metallic and fibrocement roofs in relation to their respective northern orientated slopes. Regarding orientation, roofs oriented to the North receive more Irradiation annually and therefore produce more energy. Then there is East, West and South as the most unfavorable condition.
\end{abstract}

Keywords: Global solar irradiation; Solar panel; Loss levels.

\section{Resumo}

Este trabalho teve como objetivo determinar a energia solar disponível em diferentes inclinações e orientações de telhados de edificações nas quatro estações do ano, utilizando dados de Irradiação Solar Global no plano horizontal, temperaturas e velocidade do vento. Foi simulada a irradiação solar horária inclinada e a energia gerada por sistemas fotovoltaicos de diferentes capacidades instaladas em Cascavel-PR, com diferentes orientações e inclinações e tipos de telhados (cerâmica, fibrocimento e metálica). Os dados de Irradiação Solar Global diária horizontal e velocidade do vento do SWERA (Solar and Wind Energy Resource Assessment) foram usados para simulação da irradiação solar global de inclinação diária no software PVSyst. Assim, com o software, foi determinada a energia gerada por sistemas fotovoltaicos de diferentes capacidades instaladas em Cascavel-PR, com diferentes orientações e inclinações dos 
telhados. Consequentemente, foram calculados os níveis de perdas em diferentes estações do ano e efetuada uma análise da viabilidade econômica dos empreendimentos. Assim, comparou-se as perdas, lucros e rendimentos dos sistemas. Painéis solares instalados em telhados cerâmicos orientados ao Norte proporcionaram melhor rendimento de produção de energia ao longo do ano em comparação com telhados metálicos e de fibrocimento. No entanto, para as demais orientações (Sul, Leste e Oeste), as perdas para telhados cerâmicos foram duas vezes superiores aos telhados metálicos e de fibrocimentos em relação às suas respectivas inclinações orientadas ao Norte. Quanto à orientação, telhados orientados ao Norte recebem mais irradiação anualmente e, portanto, produzem mais energia. Em seguida, tem-se Leste, Oeste e Sul como a condição mais desfavorável.

Palavras-chave: Irradiação solar global; Painel solar; Níveis de perda.

\section{Resumen}

Este trabajo tuvo como objetivo determinar la energía solar disponible en diferentes inclinaciones y orientaciones de tejados de edificaciones en las cuatro estaciones del año, utilizando datos de Irradiación Solar Global en el plano horizontal, temperaturas y velocidad del viento. Fue simulada la irradiación solar horaria inclinada y la energía generada por sistemas fotovoltaicos de diferentes capacidades instaladas en Cascavel-PR, con diferentes orientaciones e inclinaciones y tipos de tejados (cerámica, fibrocemento y metálica). Los datos de irradiación solar global diaria horizontal y velocidad del viento de SWERA se utilizaron para simular la radiación solar global de inclinación diaria en el software PVSyst. Así, se determinó la energía generada por sistemas fotovoltaicos de diferentes capacidades instaladas en Cascavel-PR, con diferentes orientaciones e inclinaciones de los tejados. Consecuentemente, se calcularon los niveles de pérdidas en diferentes estaciones del año y se efectuó un análisis de la viabilidad económica de los emprendimientos, comparando las pérdidas, beneficios e rendimentos de los sistemas. Los paneles solares instalados en techos cerámicos orientados al Norte proporcionaron un mejor rendimiento de producción de energía a lo largo del año en comparación con los techos metálicos y de fibrocemento. Sin embargo, para las demás orientaciones (Sur, Este y Oeste), las pérdidas para tejados cerámicos fueron dos veces superiores a los tejados metálicos y de fibrocemento en relación a sus respectivas inclinaciones orientadas al Norte. Los tejados orientados al Norte reciben más radiación anualmente y, producen más energía. Luego se tiene Este, Oeste y Sur como la condición más desfavorable.

Palabras clave: Radiación solar global; Panel solar; Niveles de pérdida.

\section{Introduction}

Environmental sustainability is one of the most debated topics today. World forums often discuss the use of natural resources and their preservation for future generations. Such debates also focus on the concern with the mode of energy production, which is a significant element of environmental degradation and, at the same time, the basis of human technological evolution (Santos, 2009).

Hydroelectricity is the main form of electricity that supply the existing demand today in Brazil, with about $80 \%$. However, they cause great environmental and social impact stemming from flooding in the areas in which they are deployed. In addition, the Brazilian energy sector also faces high energy demand and consequent insufficiency in its supply, generating crises such as "blackouts" in 2001, and frequent problems at peak demand times (Santos, 2009).

Due to the weather related to the rains and their regimes; the expansion of energy consumption in the contemporary world and the increasing use of non-renewable resources on the planet present themselves as great challenges to be faced by humanity and that demand increasingly creative solutions. There is, in a way, a vulnerability in the electricity grid and that cannot always meet the national demand (Takenaka, 2010).

Thus, there are renewable sources that have the advantage of generating energy without significant damage to the environment. Among the new alternatives for sustainable and clean energy production, solar photovoltaic (VF) is highlighted because it is a source of direct conversion of solar energy into electricity in a non-polluting, silent, efficient, and non-harmful way to the environment (Rüther, 2004; Siqueira, 2005).

In Brazil, with the advent of ANEEL resolution 687/2015 (ANEEL, 2015), it was allowed to install systems connected to the conventional electricity network through the credit compensation system. These systems, when used in residential consumer units, are installed on the roofs of homes. In turn, the roofs have several slopes according to the type of material used 
for roofing. In addition, they provide guidance regarding the incidence of sunlight in disagreement with the recommended orientation for the installation of photovoltaic systems.

The global solar radiation incident on a flat and horizontal surface is different from the incident radiation on a sloping surface and here will address the various forms of determination of global solar energy on a surface inclined from the global solar radiation incident on a horizontal plane. This approach is necessary to understand the mathematical modeling of software that converts this radiation.

The Brazilian territory has high potential for solar energy capture, comparatively, the regions with the highest energy availability, is the Northeast with $5.9 \mathrm{kWh} / \mathrm{m}^{2}$, due to its location closer to the Equator, the Midwest with $5.7 \mathrm{kWh} / \mathrm{m}^{2}$, Southeast $5.6 \mathrm{kWh} / \mathrm{m}^{2}$, north region with $5.5 \mathrm{kWh} / \mathrm{m}^{2}$ which, despite being close to the Equator line, receives less radiation than the previous ones because it has a rainy season during half the year, and the South $5.2 \mathrm{kWh} / \mathrm{m}^{2}$ that is further from the Equator line between the Brazilian regions (Potencial de Energia Solar no Brasil, 2016).

According to the Atlas Solar Paraná (2020), solar radiation has its unit of measurement in $\mathrm{kWh} / \mathrm{m}^{2}$ and reaches the photovoltaic module in three different ways: diffuse radiation, direct radiation and reflected radiation. Diffuse radiation reaches the earth's surface in all directions given its spread in molecules and particles in the atmosphere. Direct radiation does not undergo any displacement by the atmosphere, radiation coming directly from the sun to the photovoltaic panel. Reflected radiation, on the other hand, is the radiation that undergoes the reflection process given its incidence in a given object. Global solar radiation is any and all solar radiation that reaches the ground (it is the sum of direct radiation plus diffuse radiation plus reflected).

The global solar radiation incident on a flat and horizontal surface is a fraction of the solar radiation at the top of the atmosphere. This fraction of radiation that reaches the surface depends on local atmospheric conditions, which characterize atmospheric transmittance for shortwave radiation (Borges et al., 2010).

The determination of the values of the inclined horizontal and direct global solar radiation in the normal incidence was determined by the Angström-Prescott model described by Iqbal (1983).

On the inclined surfaces, daily direct radiation was obtained by applying the geometric factor, which translates the relationship between the radiation at the top of the atmosphere to the sloping surface and to the horizontal surface (Simonson, 1981; Iqbal, 1983; Wenxian et al., 1995).

In the southern hemisphere, the recommendation is to orient the photovoltaic systems to the true north and tilt them in this direction at an angle corresponding to the latitude of the site. This said, the hypothesis of this work is that different inclinations, orientations, and photovoltaic panels for the installation of photovoltaic systems affect the capacity of electricity generation by these systems.

In view of the above, the objective of the work was to determine the available solar energy $\left(\mathrm{kWh} / \mathrm{m}^{2}\right.$.dia) in different slopes and orientations of roofs of buildings in the four seasons of the year. And determine the energy generated $\left(\mathrm{kWh} / \mathrm{m}^{2}\right.$.dia) by photovoltaic systems on different slopes and rooftops orientations of buildings in the four seasons of the year.

\section{Methodology}

\subsection{Solar irradiation data}

In this research work, the data of horizontal daily global solar irradiation (Atlas Solar do Paraná, 2020), temperature (INMET, 2020) and wind speed (CRESESB, 2020) from the Solar and Wind Energy Resource Assessment (SWERA, 2020) database were considered. 


\subsection{Roofs and slopes of the roofs to be studied}

The work was developed considering three types of roof covers (ceramic, fiber cement and metal) and their respective inclination recommendations in accordance with NBR 15873 (ABNT, 2010). The orientation of each studied surface was considered according to the four cardinal points (North, South, East, and West).

The slope to be studied in each cardinal direction (North, South, East, and West) was defined for the ceramic roof, according to NBR 8039 (ABNT, 1983). To this end, the definition of the standard that informs that the slope of the ceramic roof must be between 32 and $40 \%$ was considered.

For the determination of the slope of metal roofs and fiber cement, the recommendation of NBR 15873 (ABNT, 2010) was considered, which suggests that these types of roofs use the data contained in the manufacturers' catalogs.

Thus, the slope data of the Technical Guide for fiber cement tiles and roof accessories of Brasilit Saint-Gobain (2014) were used, which recommends that the slope for this type of roof should be greater than $5^{\circ}$ and no more than $15^{\circ}$ of inclination.

For the metal roof, the recommended minimum slope is $8 \%$ for roofs with water length of no more than $20 \mathrm{~m}$, according to the catalog of the manufacturer Kingspan Isoeste (2018). In general, for this type of roof, the minimum possible slope is 5 to 8\%. However, technical catalogues such as Eternit Divisão - Wall (2008) are very clear about the geometric layout of this roof and the slope. Thus, the inclination for the ridge profile of $18 \%\left(\mathrm{i}=18 \%\right.$ or $\left.10^{\circ}\right)$ was adopted.

Therefore, realizing that the slope of the roof of fiber cement and metal is very close, a single slope was used to represent the inclination and orientation of the two types of roofs, fixing the slope, for the purpose of the study, in $18 \%$ ( $\mathrm{i}=18 \%$ or $10^{\circ}$ ). Thus, based on the local provisions and the average slope on which these roofs are installed, two slopes were used to represent the three types of roofs: for metal roofs and $18 \%\left(\mathrm{i}=18 \%\right.$ or $10^{\circ}$ fiber cement) and $37 \%\left(\mathrm{i}=37 \%\right.$ or $20^{\circ}$ ) for ceramic roofs.

\subsection{Calculation of solar energy available in photovoltaic systems}

The calculation of the available solar energy was performed using the PVSyst software, being available for download, free trial version for 60 days. It is a simulation software that uses vast knowledge of photovoltaic technology, meteorological data resources and components (Herzog, 2016). With the data of the solar energy available seasonally for each type of coverage, the comparison of the solar energy available in the inclined plane (as recommended for each type of roof cover) was performed for the South, East and West orientations with the solar energy available, in a plane with the same angle, oriented to the true north.

For this ratio, the percentage of solar energy available for each type of roof cover was determined in relation to the solar energy available in the ideal orientation, since the slope is fixed as the average slopes of roofs of the rattlesnake city for the respective materials. Being the ceramic slope roof closer to the local latitude where a roof with this slope would give greater use of energy.

PVSyst examines each type of coverage from the panel slope input data that the user determines to be the slope of the roof cover in design.

\subsection{Calculation of the energy generated by photovoltaic systems}

With the PVSyst software, the energy generated by photovoltaic systems of different capacities installed in the city of Cascavel - PR was determined, in the orientations (North, South, East, and West) and inclinations (18\% and 37\%). The difference from this to the available solar energy is that the energy actually generated by the panel that is product of the solar energy available on the face of the panel. This also calculates the levels of losses in different seasons. The capacities of the photovoltaic systems worked was 10 and $30 \mathrm{kWp}$ (within the microgeneration of energy). With this information, the system composition data 
and the calculation of the energy generated were obtained and, thus, the losses obtained will be calculated. Global solar radiation data on the horizontal plane and historical series were provided by PVSyst software.

\subsection{Import of solar irradiation database from U.S. Renewable Energy Laboratory - SWERA}

For data import from the U.S. Renewable Energy Laboratory, SWERA (Solar and Wind Energy Resource Assessment), the creation of tables, a model spreadsheet for importing data into PVSyst by introducing the monthly Solar Radiation, Temperature and Wind Speed values obtained from the SWERA website. Generating the synthetic data of hourly distribution of global solar irradiation in a horizontal plane, graphs, and tables available for analysis were obtained. PVSyst names synthetic data, data not collected manually, which is done through internal mathematical software modeling.

\subsection{Statistical analysis of data}

The data were obtained entirely at random (completely randomized design), using global solar irradiation data from the United States renewable energy laboratory, SWERA. The answer variables are: GlobInc, GlobEff, Earray and Egrid for the two types of slopes $\left(10^{\circ}\right.$ for metal and fiber cement roofs and $20^{\circ}$ for ceramic roofs) and the four orientations.

Knowing that the design of this experiment was completely randomized (IHD), the results were submitted to variance analysis (ANOVA), applying the F test to identify the differences between treatment means through the SISVAR (Ferreira, 2011) and then the Tukey test at 5\% significance for the means of the data using the SISVAR software.

In it, mean tests were performed, with a data arrangement, in which the variables under analysis were Global Solar Irradiation in the Inclined Plane (GlobInc); Effective Global Solar Irradiation (GlobEff); Injected Energy into the Network (Egrid).

For the level of description and importance, the two main variables under analysis that would be GlobInc and Egrid, whose analysis report will be attached in this document, will be described here.

\subsection{Economic analysis of the $10 \mathrm{kWp}$ enterprise with optimal North orientation}

The photovoltaic module used in the sizing was the Solar Photovoltaic Panel of $355 \mathrm{~W}$ of the Canadian model CS3U355P. Two strings were adopted with 15 modules, with a total of 30 modules. The panel is available for purchase on the Neo Solar website. Unit price of R $\$ 769.00$. Totaling $\mathrm{R} \$ 23,070.00$.

The sizing of the inverter can be seen in detail in the image in Annex 15. The inverter used in the sizing was the Sofar Solar Inverter model 11000 TL-X $10 \mathrm{kWp}$ available on the Techno Sun website in the amount of 2,668.03€ or R\$17,368.87. Based on the calculation, the euro price value on February 10, 2021, was $R \$ 6.51$.

The average cost of the roof ing structure available on the Solar Lumina website, sold and delivered by them, is R\$ 200.00 per module in order to freight. Totaling $\mathrm{R} \$ 6000.00$.

The average price of the installation service of a Solar Generator of $10 \mathrm{kWp}$ is $\mathrm{R} \$ 10,347.98$ according to the website of Portal Solar informs. Totaling an investment over 25 years of $\mathrm{R} \$ 56,786.85$.

\subsection{Economic analysis of the $30 \mathrm{kWp}$ enterprise with optimal North orientation}

The photovoltaic module used in the sizing was the Solar Photovoltaic Panel of $355 \mathrm{~W}$ of the Canadian model CS3U355P. Five strings with 17 modules were adopted, with a total of 85 modules. The panel is available for purchase on the Neo Solar website. Unit price of R $\$ 769.00$. Totaling R\$ 65,365.00. 
The sizing of the inverter can be seen in detail in the image in Annex 13. The inverter used in the sizing was the Sofar Solar Inverter model 33000 TL $30 \mathrm{kWp}$ available on the Techno Sun website in the amount of 6,280.48€ or R\$40,885.92. In view of the calculation made about the value of the euro price on February 10, 2021, was R\$ 6.51.

The average cost of the fixing structure for fiber cement and metal roofs available on the Solar Lumina website, sold and delivered by them, is $\mathrm{R} \$ 200.00$ per module for freight. Totaling $\mathrm{R} \$ 17,000.00$.

The average price of the installation service of a Solar Generator of $30 \mathrm{kWp}$ is $\mathrm{R} \$ 22,304.76$, as Portal Solar website informs, totaling an investment over 25 years of $\mathrm{R} \$ 145,555.68$.

\section{Results and Discussion}

\subsection{Monthly $10 \mathrm{kWp}$ system data}

Monthly results of the $10 \mathrm{~kW}$ system on two slopes and, for each slope, four orientations, which ended up generating the tables of Average Values of Global Solar Irradiation in the Inclined Plane (GlobInc); Effective Global Solar Irradiation (GlobEff); Injected Energy into the Network (Egrid).

Figure 1 of Energy Difference Generated (Energ.Dif., MWh/month), in relation to the north face of the $10 \mathrm{kWp} \mathrm{System}$ for $10^{\circ}$ slopes (metal or fiber cement cover, 18\%) and $20^{\circ}$ (ceramic cover, 37\%), and for the South, East and West orientations. In it, it is possible to observe the energy losses in MWh throughout the year for the two inclinations studied and the four orientations.

The values evidenced with the color green in Figure 1 are highlighted as infinitely variants. The values marked in yellow have a certain discrepancy reaching the red values for South to $20^{\circ}$ losing $1.02 \mathrm{MWh}$ in the month of July (winter).

Being this amount equal to $1020 \mathrm{kWh}$ and, considering the amount of $\mathrm{R} \$ 0.512 / \mathrm{kWh}$ charged by the concessionaire in force here in Paraná, COPEL (Companhia Paranaense de Energia), there is a loss of R \$ 522.24 in July if the panel is oriented to the South with a slope of $20^{\circ}$ (compared if it was oriented north with a slope of $20^{\circ}$ ).

Figure 1. Difference in Energy Generated (Energ.Dif., MWh/month), in relation to the North face of the $10 \mathrm{kWp}$ system for $10^{\circ}$ slopes (metal or fiber cement cover, $18 \%$ ) and $20^{\circ}$ (ceramic cover, 37\%), and for the South, East and West orientations.

\begin{tabular}{ccccccc}
\hline Month & $\mathbf{1 0}^{\circ} \mathbf{S}$ & $\mathbf{1 0}^{\circ} \mathbf{L}$ & $\mathbf{1 0}^{\circ} \mathbf{O}$ & $\mathbf{2 0}^{\circ} \mathbf{S}$ & $\mathbf{2 0}^{\circ} \mathbf{L}$ & $\mathbf{2 0}^{\circ} \mathbf{~}$ \\
\hline Jan & 0.03 & 0.02 & 0.01 & 0.05 & 0.04 & 0.02 \\
Feb & -0.02 & -0.01 & -0.01 & -0.04 & -0.02 & -0.01 \\
Mar & -0.13 & -0.05 & -0.09 & -0.27 & -0.08 & -0.16 \\
Apr & -0.30 & -0.14 & -0.14 & -0.59 & -0.27 & -0.26 \\
May & -0.42 & -0.21 & -0.20 & -0.83 & -0.39 & -0.39 \\
June & -0.47 & -0.23 & -0.24 & -0.94 & -0.44 & -0.44 \\
Jul & -0.52 & -0.25 & -0.25 & -1.02 & -0.48 & -0.48 \\
Aug & -0.42 & -0.21 & -0.20 & -0.84 & -0.41 & -0.37 \\
Sept & -0.16 & -0.07 & -0.09 & -0.32 & -0.13 & -0.16 \\
Oct & -0.05 & 0.00 & -0.05 & -0.11 & 0.00 & -0.10 \\
Nov & 0.02 & 0.04 & -0.02 & 0.04 & 0.08 & -0.02 \\
Dec & 0.05 & 0.04 & 0.02 & 0.10 & 0.08 & 0.03 \\
\hline
\end{tabular}

Source: Authors. 


\subsection{Monthly $30 \mathrm{kWp}$ system data}

Monthly results for the $30 \mathrm{kWp}$ system on both slopes and, on each slope, four orientations. Generating the Tables of Average Values of Global Solar Irradiation in the Inclined Plane (GlobInc); Effective Global Solar Irradiation (GlobEff); Injected Energy into the Network (Egrid).

Figure 2 of Generated Energy Difference (Energ.Dif., MWh/month) in relation to the North face of the $10 \mathrm{kWp}$ System for $10^{\circ}$ slopes (metal or fiber cement cover, $18 \%$ ) and $20^{\circ}$ (ceramic cover, 37\%), and for the South, East and West orientations. In it, one can observe the energy losses in MWh throughout the year for the two inclinations studied and the four orientations.

Figure 2. Difference in Energy Generated (Energ.Dif., MWh/month), in relation to the North face of the $30 \mathrm{kWp}$ system for $10^{\circ}$ slopes (metal or fiber cement cover, 18\%) and $20^{\circ}$ (ceramic cover, 37\%), and for the South, East and West orientations.

\begin{tabular}{ccccccc}
\hline Month & $\mathbf{1 0}^{\circ} \mathbf{S}$ & $\mathbf{1 0}^{\circ} \mathbf{L}$ & $\mathbf{1 0}^{\circ} \mathbf{O}$ & $\mathbf{2 0}^{\circ} \mathbf{S}$ & $\mathbf{2 0}^{\circ} \mathbf{L}$ & $\mathbf{2 0}^{\circ} \mathbf{O}$ \\
\hline Jan & 0.08 & 0.05 & 0.02 & 0.16 & 0.12 & 0.06 \\
Feb & -0.06 & -0.03 & -0.02 & -0.12 & -0.04 & -0.03 \\
Mar & -0.38 & -0.13 & -0.25 & -0.76 & -0.24 & -0.46 \\
Apr & -0.84 & -0.40 & -0.39 & -1.67 & -0.75 & -0.75 \\
May & -1.18 & -0.58 & -0.58 & -2.35 & -1.11 & -1.11 \\
June & -1.35 & -0.66 & -0.67 & -2.67 & -1.24 & -1.26 \\
Jul & -1.47 & -0.72 & -0.72 & -2.90 & -1.37 & -1.35 \\
Aug & -1.21 & -0.61 & -0.55 & -2.40 & -1.15 & -1.06 \\
Sept & -0.45 & -0.20 & -0.25 & -0.90 & -0.37 & -0.45 \\
Oct & -0.15 & 0.00 & -0.16 & -0.30 & 0.01 & -0.29 \\
Nov & 0.06 & 0.11 & -0.05 & 0.11 & 0.22 & -0.07 \\
Dec & 0.15 & 0.12 & 0.05 & 0.29 & 0.24 & 0.10 \\
\hline
\end{tabular}

Source: Authors.

The values marked with the green color as infimamente variants stand out. The values in yellow have a certain discrepancy reaching the red values for South to $20^{\circ}$ losing $2.90 \mathrm{MWh}$ in the month of July (winter).

Since this amount is equal to $2900 \mathrm{kWh}$ and, considering the amount of $\mathrm{R} \$ 0.512 / \mathrm{kWh}$ charged by the concessionaire in force in Paraná, COPEL (Companhia Paranaense de Energia), there is a loss of $R \$ 1,484.80$ in July if the panel is tilted and oriented to $20^{\circ}$ to the South (compared if it was oriented north with a $20^{\circ}$ slope).

\section{$3.310 \mathrm{kWp}$ system annual data}

Annual system results of $10 \mathrm{kWp}$ for the two inclinations and, in each inclination, four orientations (Table 1), where the mean values of Global Solar Irradiation in the Inclined Plane (Globinc); Effective Global Solar Irradiation (Globeff) are highlighted; Injected Energy in the Network (Egrid); the Differential Energy in relation to the North face (Energ.Dif) for the Orientation of $10^{\circ}$. 
Table 1. Average Annual Global Solar Irradiation Values in the Inclined Plane (GlobInc); Effective Global Solar Irradiation (GlobEff); Injected Energy into the Grid (Egrid); differential energy in relation to the North face (Energ.Dif) for the $10^{\circ}$ Orientation.

\begin{tabular}{cccccc}
\hline Orientation & GlobInc $\left(\mathbf{k W h} / \mathbf{m}^{2}\right)$ & GlobEff $\left(\mathbf{k W h} / \mathbf{m}^{\mathbf{2}}\right)$ & Egrid (MWh) & Energ. Dif. (\%) & Energ.Dif. (MWh/ano) \\
\hline $\mathbf{N}$ & 1915.30 & 1867.80 & 17.16 & 100.00 & - \\
$\mathbf{S}$ & 1647.60 & 1591.60 & 14.77 & 86.08 & -2.39 \\
$\mathbf{E}$ & 1791.20 & 1742.00 & 16.09 & 93.75 & -1.07 \\
$\mathbf{O}$ & 1774.50 & 1724.70 & 15.90 & 92.69 & -1.25 \\
\hline
\end{tabular}

Source: Authors.

North has higher production of Generated Energy, second is East with 93.75\%. In third place, it is West with 92.69\% and, finally, South with $86.08 \%$. Next, in MWh/year, you have the energy lost by the system in the month in each orientation.

For the South, the annual energy loss compared to the North is $2.39 \mathrm{MWh} / \mathrm{year}$, followed by $1.25 \mathrm{MWh} / \mathrm{year}$ for the West and $1.06 \mathrm{MWh} /$ year to the East.

Table 2 shows the mean values of Global Solar Irradiation in the Inclined Plane (GlobInc); Effective Global Solar Irradiation (GlobEff); Injected Energy into the Grid (Egrid); differential energy in relation to the North face (Energ.Dif) for the $20^{\circ}$ Orientation.

Table 2. Average Annual Global Solar Irradiation Values in the Inclined Plane (GlobInc); Effective Global Solar Irradiation (GlobEff); Injected Energy into the Grid (Egrid); differential energy in relation to the north face (Energ.Dif) for the 20 Orientation.

\begin{tabular}{cccccc}
\hline Orientation & GlobInc $\left(\mathbf{k W h} / \mathbf{m}^{2}\right)$ & GlobEff $\left(\mathbf{k W h} / \mathbf{m}^{\mathbf{2}}\right)$ & Egrid (MWh) & Energ. Dif. (\%) & Energ.Dif. (MWh/ano) \\
\hline $\mathbf{N}$ & 1990.10 & 1947.50 & 17.81 & 100.00 & - \\
$\mathbf{S}$ & 1463.10 & 1402.10 & 13.07 & 73.34 & -4.75 \\
$\mathbf{E}$ & 1759.10 & 1713.50 & 15.81 & 88.76 & -2.00 \\
$\mathbf{O}$ & 1726.70 & 1680.00 & 15.47 & 86.81 & -2.35 \\
\hline
\end{tabular}

Source: Authors.

North has higher production of Generated Energy, second is East with $88.76 \%$. In third place, it is West with $86.81 \%$ and, finally, South with 73.34\%. Next, in MWh/year, you have the energy lost by the system in the month in each orientation. Presenting approximately twice the system loss when it is at $20^{\circ}$ compared to the $10^{\circ}$ oriented system.

For south, the annual energy loss compared to the North is $4.75 \mathrm{MWh} /$ year, followed by $2.35 \mathrm{MWh} /$ year for west and $2.00 \mathrm{MWh} / \mathrm{year}$ to east. It is noted that the losses have doubled approximately in relation to losses for the $10^{\circ}$ slope.

\section{$3.430 \mathrm{kWp}$ system annual data}

Annual results for the $30 \mathrm{kWp}$ system in both inclinations and, for each slope, four orientations generating Table 3, where the mean values of Global Solar Irradiation in the Inclined Plane (GlobInc) are evidenced; Effective Global Solar Irradiation (GlobEff); Injected Energy into the Grid (Egrid); differential energy in relation to the North face (Energ.Dif) for the $10^{\circ}$ Orientation. 
Table 3. Average Annual Global Solar Irradiation Values in the Inclined Plane (GlobInc); Effective Global Solar Irradiation (GlobEff); Injected Energy into the Grid (Egrid); differential energy in relation to the North face (Energ.Dif) for the $10^{\circ}$ Orientation.

\begin{tabular}{cccccc}
\hline Orientation & GlobInc $\left(\mathbf{k W h} / \mathbf{m}^{2}\right)$ & GlobEff $\left(\mathbf{k W h} / \mathbf{m}^{2}\right)$ & Egrid $(\mathbf{M W h})$ & Energ. Dif. (\%) & Energ.Dif. (MWh/ano) \\
\hline $\mathbf{N}$ & 1915.30 & 1867.80 & 48.71 & 100.00 & - \\
$\mathbf{S}$ & 1647.60 & 1591.60 & 41.93 & 86.08 & -6.78 \\
$\mathbf{E}$ & 1791.20 & 1742.00 & 45.66 & 93.74 & -3.05 \\
$\mathbf{O}$ & 1774.50 & 1724.70 & 45.15 & 92.69 & -3.56 \\
\hline
\end{tabular}

Source: Authors.

North has higher production of Generated Energy, second to the East with 93.74\%. In third place, it is West with 92.69\% and, finally, South with $86.08 \%$. Next to it, in MWh/year, is the energy lost by the system in the month at each orientation.

For the South, the annual energy loss compared to the North is $6.78 \mathrm{MWh} / \mathrm{year}$, followed by $3.56 \mathrm{MWh} / \mathrm{year}$ for the West and 3.05 MWh/year to the East.

Table 4 highlights the mean values of Global Solar Irradiation in the Inclined Plane (GlobInc); Effective Global Solar Irradiation (GlobEff); Injected Energy into the Grid (Egrid); differential energy in relation to the North face (Energ.Dif) for the Orientation of $20^{\circ}$.

Table 4. Average Annual Global Solar Irradiation Values in the Inclined Plane (GlobInc); Effective Global Solar Irradiation (GlobEff); Injected Energy into the Grid (Egrid); differential energy in relation to the North face (Energ.Dif) for the Orientation of $20^{\circ}$.

\begin{tabular}{cccccc}
\hline Orientation & GlobInc $\left(\mathbf{k W h} / \mathbf{m}^{2}\right)$ & GlobEff $\left(\mathbf{k W h} / \mathbf{m}^{2}\right)$ & Egrid $(\mathbf{M W h})$ & Energ. Dif. (\%) & Energ.Dif. (MWh/ano) \\
\hline $\mathbf{N}$ & 1990.10 & 1947.50 & 50.57 & 100.00 & - \\
$\mathbf{S}$ & 1463.10 & 1402.10 & 37.08 & 73.32 & -13.49 \\
$\mathbf{E}$ & 1759.10 & 1713.50 & 44.89 & 88.76 & -5.69 \\
$\mathbf{O}$ & 1726.70 & 1680.00 & 43.90 & 86.80 & -6.67 \\
\hline
\end{tabular}

Source: Authors.

North has higher production of Generated Energy, second is East with $88.76 \%$. Third, there is West with $86.80 \%$ and, finally, South with $73.32 \%$. Next to it, in MWh/year, is the energy lost by the system in the month at each orientation. Presenting approximately twice the system loss when it is at $20^{\circ}$ compared to the $10^{\circ}$ oriented system.

For the South, the annual energy loss compared to the North is $13.49 \mathrm{MWh} /$ year, followed by $6.67 \mathrm{MWh} / \mathrm{year}$ for the West and 5.69 MWh/year to the East. It is noted that the losses have doubled approximately in relation to the losses for the $10^{\circ}$ slope.

In the tables, you can compare the energy losses for the orientations for the two inclinations in the 4 powers. It is possible to conclude that the Available Energy relative to the North face for $20^{\circ}$ slope is approximately twice as much as the Available Energy for the $10^{\circ}$ slope.

\subsection{Statistical analysis: Tukey test for INCL FV (slope)}

Table 5 shows the Tukey Test for Slope (Inc.), Global Solar Irradiation in the Inclined Plane (GlobInc) and Network Injected Energy (Egrid). 
Table 5. Tukey Test Table for Slope Variation Source (Inc.), Global Solar Irradiation on the Inclined Plane (GlobInc) and The Injected Power into the Network (Egrid). Averages followed by the same lowercase letter in the row and uppercase in the column do not differ from each other by the Tukey test at the significance level of 5 . Treatment tilt $10^{\circ}$ and $20^{\circ}$.

\begin{tabular}{ccc}
\hline Inc. & GlobInc $\left(\mathbf{k W h} / \mathbf{m}^{2}\right)$ & Egrid $(\mathbf{M W h})$ \\
\hline 10 & $149.26 \mathrm{a}$ & $2.09 \mathrm{a}$ \\
20 & $144.57 \mathrm{~b}$ & $2.03 \mathrm{a}$ \\
\hline
\end{tabular}

Source: Authors.

Table 5 shows the equality and differences between treatments. There was a difference between treatments for Global Solar Irradiation in the Inclined Plane for the two inclinations. For the Energy Injected into the Network, the values do not differ statistically.

\subsection{Statistical analysis: Tukey test for Pot FV (power)}

Table 6 shows the Tukey Test for source of Power variation (Pot.), Global Solar Irradiation on the Inclined Plane (GlobInc) and The Injected Power into the Network (Egrid).

Table 6. Tukey Test Table for Power (Pot.), Global Solar Irradiation on the Inclined Plane (GlobInc) and The Injected Power into the Network (Egrid). Averages followed by the same lowercase letter in the row and uppercase in the column do not differ from each other by the Tukey test at the significance level of 5. Power treatment of 5, 10, 20 and $30 \mathrm{kWp}$.

\begin{tabular}{|c|c|c|}
\hline (Pot.) & GlobInc $\left(\mathrm{kWh} / \mathrm{m}^{2}\right)$ & Egrid (MWh) \\
\hline 10 & $146.91 \mathrm{a}$ & $1.31 \mathrm{c}$ \\
\hline 30 & $146.91 \mathrm{a}$ & $3.73 \mathrm{a}$ \\
\hline
\end{tabular}

Source: Authors.

Table 6 shows the equality and differences between treatments. There was no difference between treatments for Global Solar Irradiation in the Inclined Plane for the four powers. For the Energy Injected into the Network, the values differ statistically because they appear as different powers.

\subsection{Statistical analysis: Tukey test for ORIEN VF (guidance)}

Table 7 highlights the Tukey Test for source of orientation variation (Orien), Global Solar Irradiation in the Inclined Plane (GlobInc) and The Energy Injected into the Network (Egrid).

Table 7. Tukey Test Table for Guidance Source (Orien.), with the mean values of Global Solar Irradiation in the Inclined Plane (GlobInc) and The Injected Energy into the Network (Egrid). Averages followed by the same lowercase letter in the row and uppercase in the column do not differ from each other by the Tukey test at the significance level of 5 . Treatment orientation North (N), East (L), West (O) and South (S).

\begin{tabular}{ccc}
\hline Orien. & GlobInc $\left(\mathbf{k W h} / \mathbf{m}^{2}\right)$ & Egrid $(\mathbf{M W h})$ \\
\hline N & $162.73 \quad \mathrm{a}$ & $2.28 \mathrm{a}$ \\
$\mathrm{E}$ & $149.43 \mathrm{~b}$ & $2.08 \mathrm{~b}$ \\
$\mathrm{O}$ & $145.89 \mathrm{~b}$ & $2.05 \mathrm{~b}$ \\
$\mathrm{~S}$ & $129.61 \mathrm{c}$ & $1.82 \mathrm{c}$ \\
\hline
\end{tabular}

Source: Authors. 
Table 7 shows the equalities and differences between treatments. There was a difference between treatments for Global Solar Irradiation in the Inclined Plane for the four orientations. For the Energy Injected into the Network, the values suffered the same difference. Table 5 shows that the slope affects with statistical difference only the Global Solar Irradiation in the Inclined Plane, not statistically affecting the Energy Injected into the Network. However, for the source of orientation variation, there is a statistical difference in both, being equal the treatments $\mathrm{E}$ and $\mathrm{O}$ (east west).

The results found in relation to orientation and inclination through the results of the analysis support the discussion. Therefore, the energy generated (a) by systems with $10^{\circ}$ and $20^{\circ}$ inclinations are statistically equal. Differ only in global solar irradiation in the inclined plane (b). In the case of the guidelines, it is perceived that North generates more energy (a) than the other. East and West are second with their irradiation and energy values generated (b) statistically equal. Finally, there is the Southern orientation with lower values (c).

The ideal inclination behaves as highlighted in the study by Nóbrega, Lima, Melo, Gonçalves and Wanderley Neto (2018). In the proposed work, it is possible to verify the results of the annual energy production as a function of the variation of the angle of inclination and azimutal orientation of the photovoltaic panels simulated in the SAM and normalized by the ideally oriented system (Nóbrega et al., 2018).

The analysis of the results of the Nóbrega et al. (2018) simulations shows that the energy produced by the panel for the $10^{\circ}$ slope is numerically higher than a panel with a $20^{\circ}$ inclination. However, statistically the energy values produced for both slopes are equal. This is a classic example where there is a set of data that differs from each other but is statistically equal, that is, they have the same probability of happening. Therefore, the H0 hypothesis (that the generated energy does not differ statistically as a function of the slope variation) is accepted for the energy generated by the panel.

On the other, the global solar irradiation incident on the surface is higher for the slope of $20^{\circ}$ than for $10^{\circ}$ in the city of Cascavel -PR. In accordance with what the equations and every theory seen in the review of this work: the ideal angle for orientation is corresponding to the local latitude of the city under study.

The city of Cascavel-PR has latitude S $24^{\circ} 57^{\prime} 21^{\prime \prime}$, this being the ideal slope with true north orientation for the highest Global Solar Irradiation Incident and power generation. Therefore, data from Nóbrega et al. (2018) show that the highest incident Global Solar Irradiation occurs at the $10^{\circ}$ slope, with cities in low latitudes analysis around 5 to $10^{\circ} \mathrm{S}$. Therefore, the ideal slope is $10^{\circ}$. Note the variability of the slope and ideal orientation according to the geodesical coordinate of the locality.

\subsection{Economic and financial viability of the $10 \mathrm{kWp}$ enterprise with optimal North orientation}

The investment of R $\$ 56,786.85$ (Table 8) has the energy generated in 25 years of approximately $437,000 \mathrm{kWh}$. In view of the current tariff of $\mathrm{R} \$ 0,512 / \mathrm{kWh}$, savings of $\mathrm{R} \$ 223,744$ have been made over 25 years, considering the value of the constant tariff, which would be almost impossible, because the value of electricity always tends to increase due to the growing demand and the current Brazilian energy scenario. For didactic purposes, the value of the constant tariff is adopted as the safety coefficient of our calculation of the minimum floor of return on investment.

Table 8. Project cost for $10 \mathrm{kWp}$ system.

\begin{tabular}{cc}
\hline Investment (Equip. + Labour) & $\mathrm{R} \$ 56,786.85$ \\
\hline Maintenance (after 25 years) & $\mathrm{R} \$ 5,000.00$ \\
Total Cost & $\mathrm{R} \$ 61,786.85$ \\
\hline
\end{tabular}

Source: Authors 
Obtaining a return on investment with a power system $10 \mathrm{kWp}$ oriented to the North in the inclinations of $10^{\circ}$ or $20^{\circ}$ of $\mathrm{R} \$ 161,957.15$ over the 25 years, equal for both inclinations, because, as observed in Table 8 , there is no variation as to the generation of energy for both inclinations, with $262 \%$ of profit in relation to the invested capital.

\subsection{Economic and financial viability of the $30 \mathrm{kWp}$ venture with ideal North orientation}

The investment of R\$ 145,555.68 (Table 9) has the energy generated in 25 years of approximately 1,226,000 kWh. In view of the current rate of $\mathrm{R} \$ 0,512 / \mathrm{kWh}$, savings of $\mathrm{R} \$ 1,226,000$ have been made over 25 years, based on the value of the constant tariff, which would be almost impossible, because the value of electricity always tends to increase due to the growing demand and the current Brazilian energy scenario. For didactic purposes, the value of the constant tariff is adopted as the safety coefficient of our calculation of the minimum floor of return on investment.

Table 9. Project cost for $30 \mathrm{kWp}$ system.

\begin{tabular}{cc}
\hline Investment (Equip. + Labour) & $\mathrm{R} \$ 145.555,68$ \\
\hline Maintenance (after 25 years) & $\mathrm{R} \$ 5.000,00$ \\
Total Cost & $\mathrm{R} \$ 150.555,68$ \\
\hline
\end{tabular}

Source: Authors

Obtaining a return on investment with a $30 \mathrm{kWp}$ power system oriented to the North in the inclinations of $10^{\circ}$ or $20^{\circ}$ of $\mathrm{R} \$ 1,075,444.32$ over the 25 years, equal for both inclinations, because, as observed in Table 8 , there is no variation as to the generation of energy for both inclinations, with $714 \%$ of profit in relation to the invested capital.

The highlights of the work were: the global solar irradiance in the Inclined Plane was higher for the slope of $20^{\circ}$ (ceramic ceilings, $32 \%$ ) and $10^{\circ}$ slope (metal cement and fiber roofs, $18 \%$ ). The angle of $20^{\circ}$ was closer to the local latitude than the inclination of $10^{\circ}$. Northern-facing roofs receive more irradiation annually and produce more energy. Followed, from the west and east with equal treatment. The southern orientation was the most unfavorable condition. A generator of $10 \mathrm{kWp}$ in $25 \mathrm{years}$ will give a return of $\mathrm{R} \$ 161.957,15$ while a system of $30 \mathrm{kWp}$, will give a return of $\mathrm{R} \$ 1.075 .444,32$ in the same 25 years.

\section{Conclusion}

The research pointed out that global solar irradiance in the Inclined Plane was higher for the slope of $20^{\circ}$ (ceramic roofs, $32 \%) 10^{\circ}$ slope (metal and fiber cement roofs, 18\%) in Cascavel-PR. The ideal inclination for maximum utilization corresponds to local latitude corroborating the theories in the review of this work. The angle of $20^{\circ}$ is closer to the local latitude - of the city studied in this work, Cascavel - PR, with latitude S 24\%57'21" - than the slope of $10^{\circ}$.

Regarding the energy that can be generated in each direction and each typical slope of the roofs under study, it was concluded that the most unfavorable condition for photovoltaic power generation corresponds to the southern direction in ceramic roofs $\left(20^{\circ}\right)$.

With regard to orientation, north-oriented roofs receive more irradiation annually and therefore produce more energy. Secondly, it would come west and east with equality between treatments. Finally, there is the Southern orientation as the most unfavorable condition.

Solar panels installed on north-facing ceramic roofs provide better energy production throughout the year. However, for the other orientations (South, East and West), the losses for ceramic roofs were twice as high as the metal and fiber cement roofs in relation to their respective north-oriented inclinations. 
Note that the profit of the enterprise becomes greater the higher the system (power) adopted. A generator of $10 \mathrm{kWp}$ in 25 years will give a return of $\mathrm{R} \$ 161,957.15$ while a system 3 times larger, $30 \mathrm{kWp}$, will give a return of 1,075,444.32 in the same 25 years.

Some considerations about the research carried out are listed, so that they serve as parameters of decision-making or readers' analysis.

It was noted that only northern-oriented roofs produce more energy for the $20^{\circ}$ slope (closest to ideal). For the rest, it was noted that the $10^{\circ}$ tilted roof produced more energy and received greater global inclined solar irradiation.

It was noted that the ideal inclination of a panel varies according to its orientation.

\section{References}

ABNT. (2010). Associação Brasileira de Normas Técnicas. NBR 15873: Coordenação modular para edificações. ABNT, 4p.

ABNT. (1983). Associação Brasileira de Normas Técnicas. NBR 8039: Projeto e execução de telhados com telhas cerâmicas tipo francesa - Procedimento. ABNT, 5p.

ANEEL (2015). Agência Nacional de Energia Elétrica. Resolução Normativa No 687, de 24 de novembro de 2015. ANNEL, 26p.

Atlas Solar Paraná. 2020. Atlas de Energia Solar do Paraná. http://atlassolarparana.com.

Borges, V. P., Oliveira, A. S., Coelho Filho, M. A., Silva, T. S. M., \& Pamponet, B. M. (2010). Avaliação de modelos de estimativa da radiação solar incidente em Cruz das Almas, Bahia. Revista Brasileira de Engenharia Agrícola e Ambiental, 14 (1), 74-80. 10.1590/S1415-43662010000100010

Brasilit Saint-Gobain. (2014). Guia técnico de telhas de fibrocimento e acessórios para telhados. http://www.brasilit.com.br/pdf/catalogo-tecnico-fibrocimento210x297mm-AF-29-09.pdf?v=1.

CRESESB. (2020). Centro de Referência para Energia Solar e Eólica Sérgio de Salvo Brito. CEPEL. 2020 - Centro de Pesquisas de Energia Elétrica. Cidade Universitária. http://www.cresesb.cepel.br.

Eternit Divisão - Wall. (2008). Telhas metálicas - Catálogo Técnico. http://www.aecweb.com.br/cls/catalogos/eternit/telha_termoacustica.pdf.

Ferreira, D. F. (2011). Sisvar: A computer statistical analysis system. Ciência e Agrotecnologia, 35, 1039-1042. 10.1590/S1413-70542011000600001

Herzog, O. (2016). PVSYST - Software de Simulação de Sistemas Fotovoltaicos. http://www.solarize.com.br/cursos-e-eventos/pvsyst-avancado-software-desimulacao-de-sistemas-fotovoltaicos/turmas/31.

INMET. (2020). Instituto Nacional de Meteorologia. Banco de dados meteorológicos. http://www.inmet.gov.br.

IqbaL, M. (1983). An introduction to solar radiation. Ed. AP. Vancouver. 389p.

Kingspan Isoeste. (2018). Telha metálica standard. http:www.isoeste.com.br/portfolio_item/metálica-standard-tp40/.

Nóbrega, B. S., Lima, W. G., Melo, R. H. F., Gonçalves, M. C. P., \& Wanderley Neto, A. C. (2018). Desempenho de um sistema solar fotovoltaico com diferentes inclinações e orientações azimutais em cidades da Paraíba. Revista Principia - Divulgação Científica e Tecnológica do IFPB, 43, 175-188. 10.18265/151703062015v1n43p175-188

Potencial de energia solar no Brasil. (2016). Radiação Solar no Brasil. http://borealsolar.com.br/blog/2016/10/26/potencial-de-energia-solar-quais-as-melhoresregioes-brasileiras-para-captacao-da-luz-solar/.

Rüther, R. (2004). Edifícios Solares Fotovoltaicos: O Potencial da Geração Solar Fotovoltaica Integrada a Edificações Urbanas e Interligada à Rede Elétrica Pública no Brasil. UFSC/LABSOLAR. 114p.

Santos, I. P. (2009). Integração de painéis solares fotovoltaicos em edificaçães residenciais e sua contribuição em um alimentador de energia de zona urbana mista. Dissertação de Mestrado. Engenharia Civil, Universidade Federal de Santa Catarina.148p.

Simonson, J. R. (1981). The use of weighted $\mathrm{Rb}$ factors in calculating monthly average insolation on tilted surfaces. Solar Energy, 27 (3), $455-447$. $10.1016 / 0038-092 \mathrm{X}(81) 90011-6$

Siqueira, J. A. C. (2005). Desempenho de um sistema híbrido eólico-fotovoltaico de pequeno porte para energização rural. Tese de Doutorado. Energia na Agricultura, Universidade Estadual Paulista "Júlio de Mesquita Filho", Faculdade de Ciências Agronômicas, Campus de Botucatu. 176p.

Swera. (2020). Solar and Wind Energy Resource Assessment. http://openei.org/wiki/Solar_and_Wind_Energy_Resource_Assessment_(SWERA).

Takenaka, F. O. (2010). Avaliação do potencial de geração de energia solar fotovoltaica na cobertura das edificações do campus I-Cefet - MG, interligado à rede elétrica. Dissertação de Mestrado. Engenharia Civil, Universidade Federal de Santa Catarina. 154p.

Wenxian, L., Enrong, L., Wenfeng, G., Shaoxuan, P., \& Tao, T. (1996). Distribution patterns of diffuse solar radiation in Yunnan province, China. Energy Conversion and Management, 37 (5), 553-560, 1996. 10.1016/0196-8904(95)00210-3 